\title{
A Huge Anterior Urethral Diverticulum After Circumcision in a Child: An Unusual Complication of Disposable Plastic Circumcision Device
}

\section{Plastik Sünnet Klemplerinin Nadir Bir Komplikasyonu: Bir Çocukta Sünnet Sonrası Gelişen Dev Üretral Divertikül Olgusu}

\author{
(D) Özlem Balcı, (D) İbrahim Karaman, (D) Ayşe Karaman \\ Dr. Sami Ulus Maternity and Child Health and Diseases Training and Research Hospital, Clinic of Pediatric Surgery, Ankara, Turkiye
}

\begin{abstract}
Urethral diverticula are very rare conditions in boys and may occur due to congenital or acquired reasons. Post-circumcision urethral diverticulum has not been previously reported in the literature. Here, we present a case of an acquired urethral diverticulum due to its unusual etiology.

Keywords: Urethral diverticulum, Circumcision, Child
\end{abstract}

Öz

Üretral divertiküller erkek çocuklarda oldukça nadiren görülür ve konjenital ya da akiz bir nedene bağlı olarak gelişebilir. Sünnet sonrası üretral divertikül gelişimi daha önce literatürde bildirilmemiş olup, olgumuz sıradışı bir etiyolojiye bağlı üretral divertikül gelişimi nedeniyle sunulmuştur. Anahtar Kelimeler: Üretral divertikül, Sünnet, Çocuk

\section{Introduction}

Urethral diverticulum is defined as a localized outpouching of the urethra and is very rare in boys. A urethral diverticulum may have a narrow or wide connection to the urethra and therefore may be seen in different shapes (1). A urethral diverticulum caused by circumcision has not been reported in the literature, and here, we present a case of acquired urethral diverticulum due to its unusual etiology.

\section{Case Presentation}

A 4-year-old male patient presented with the complaints of swelling on the shaft of the penis, dysuria, and post-voiding dribbling. In his past medical history, he had a circumcision procedure with plastic clamp technique six months ago and his complaints had started after this procedure. He had no urinary complaints before the procedure. After insertion of the circumcision clamp, he became unable to urinate and groin swelling was observed, thus, he was readmitted to the hospital the day after circumcision procedure. The circumcision clamp was removed immediately and a urinary catheter was inserted into the bladder. A urethral injury was suspected and he was hospitalized for one week with urinary catheter and discharged after removal of the catheter. Although the patient was able to urinate normally after discharge, penile swelling appeared later and gradually increased.

On his physical examination, there was a massive swelling on the ventral root of the penis beginning from the penoscrotal region, and urine coming out through the urethra when pressed on it (Figure 1). Ultrasonography revealed a localized subcutaneous collection measuring $33 \mathrm{~mm}$ in length and $20 \mathrm{~mm}$ in width on the ventral root of the penis. Retrograde urethrogram showed a large periurethral pouch (Figure 2). The pouch was in connection with the distal part of urethra and filled with contrast material given from external urethral meatus. In the diagnostic cystoscopy, the connection point of the urethra with the diverticular neck was noted at a distance of $1.5 \mathrm{~cm}$ from the external urethral meatus. Later, the diverticulum was assessed

Correspondence: Özlem Balcı MD, Dr. Sami Ulus Maternity and Child Health and Diseases Training and Research Hospital, Clinic of Pediatric Surgery, Ankara Turkiye Phone: +90 3124123000 E-mail: drozlembalci@gmail.com ORCID-ID: orcid.org/0000-0002-4926-5451

Received: 13.02.2019 Accepted: 13.03.2019

Cite this article as: Balcı Ö, Karaman I, Karaman A. A Huge Anterior Urethral Diverticulum After Circumcision in a Child: An Unusual Complication of Disposable Plastic Circumcision Device. J Urol Surg 2019;6(2):165-167.

${ }^{\circ}$ Copyright 2019 by the Association of Urological Surgery / Journal of Urological Surgery published by Galenos Publishing House. 
with a midline incision at the penoscrotal junction. The giant diverticulum was extending from the coronal region to the middle of the scrotum and was surrounding the ventral half of the penis body (Figure 3). The diverticulum was dissected from the surrounding tissue adhesions and was opened from its anterior aspect. A narrow stalk connection to the coronal part of the urethra was detected. Diverticulectomy was performed and the defect in the urethra was repaired with two layers. No intra- and post-operative complications occurred. The urinary

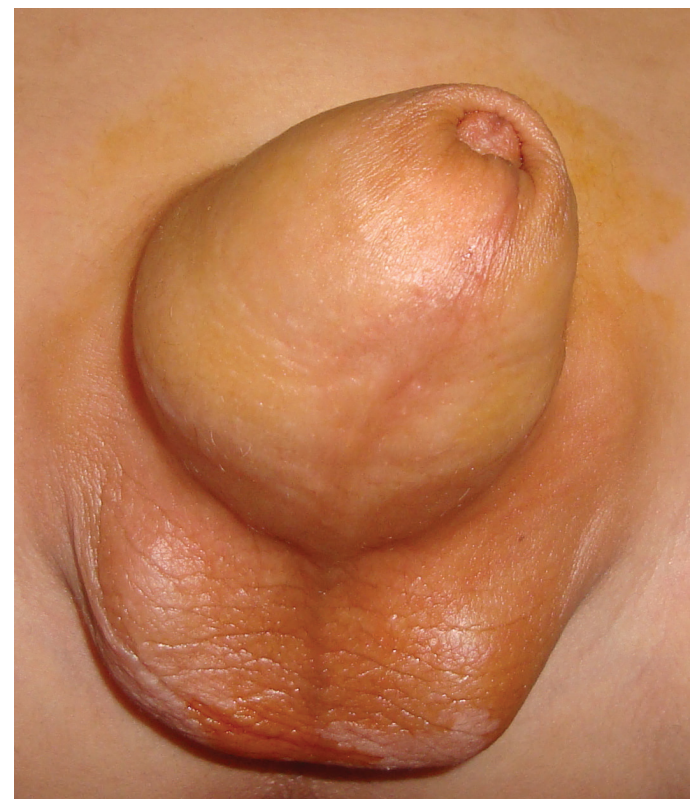

Figure 1. There is a swelling extending to the scrotum in the ventral aspect of the penis due to the urethral diverticulum

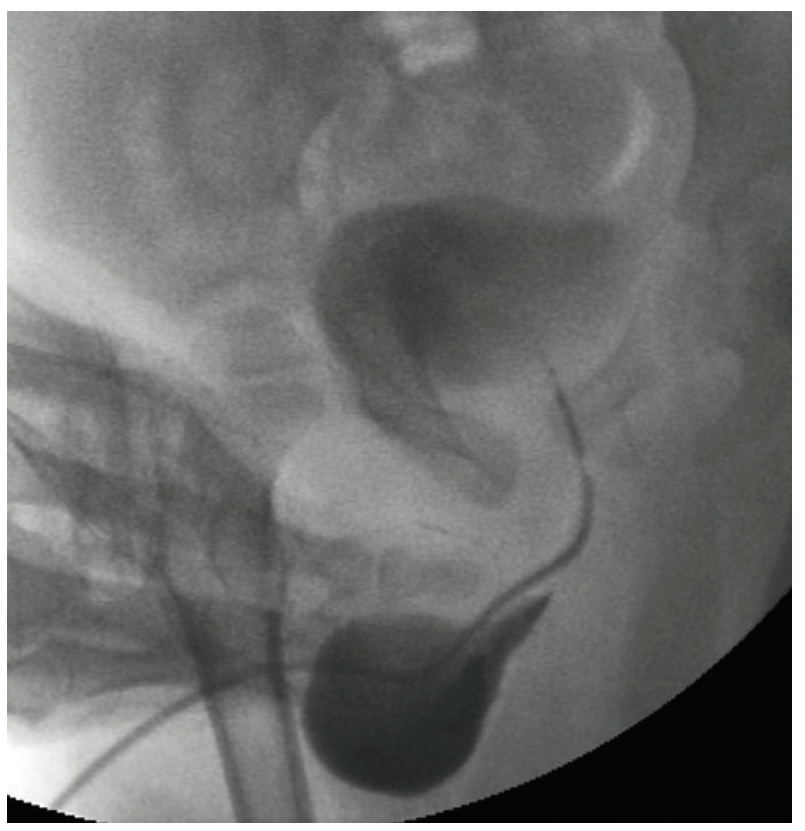

Figure 2. Retrograde urethrography of the giant urethral diverticulum arising from the distal penile urethra and having a very narrow stalk catheter was removed on the postoperative $7^{\text {th }}$ day and the patient urinated without any complications (Figure 4). The histopathological examination revealed a diverticulum structure with urothelial epithelium and a wall composed of fibrous connective tissue. The six-year follow-up was uneventful.

\section{Discussion}

Urethral diverticula may be congenital or acquired. Congenital diverticula may develop due to an anterior urethral valve or urethral duplication and can cause serious problems in the upper urinary tract starting from the intrauterine period similar to the posterior urethral valve $(1,2)$.

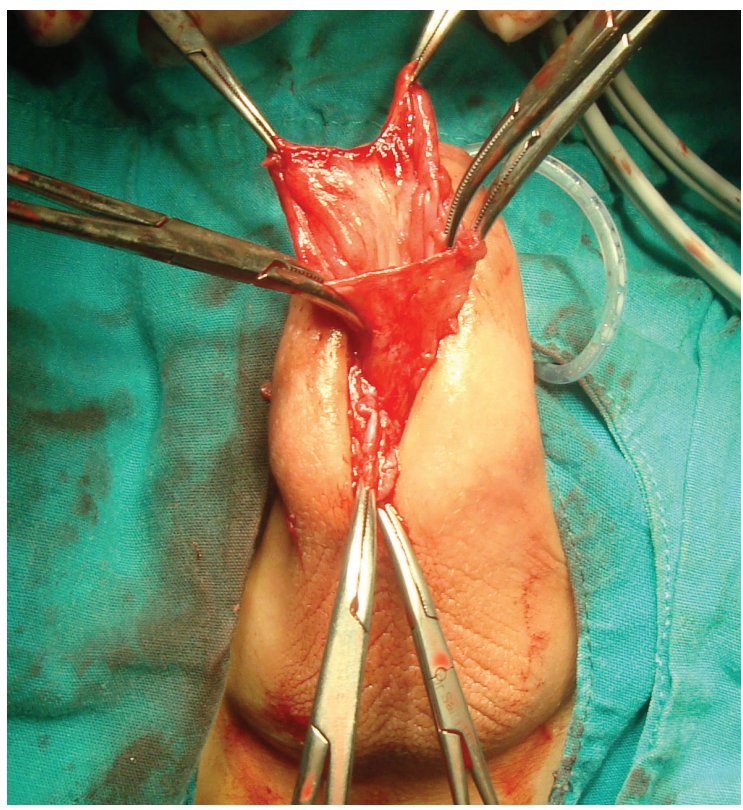

Figure 3. Intraoperative image of giant anterior urethral diverticulum

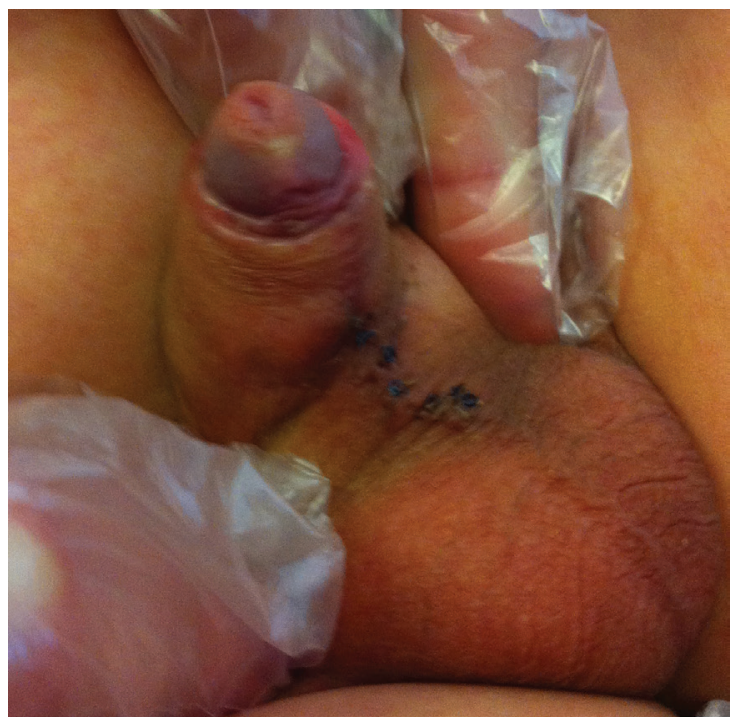

Figure 4. Appearance 1-month after surgery 
In the etiology of acquired diverticula, urethral trauma, catheterization, instrumentation, infection, and obstruction are the main culprits. Acquired diverticula usually develop at the fixed points of the urethra, such as the penoscrotal junction and, more often, the proximal bulbous part (2).

As in our case, urethral diverticula may present with swelling on the penoscrotal region that increase during urination, dysuria, weak urine stream, and post-voiding dribbling. It may be complicated by urinary tract infection and stone development in the diverticulum (1). The diagnosis is usually confirmed by micturating cystourethrography or retrograde urethrogram. Urethral diverticulectomy with urethroplasty is the recommended treatment, as in our case $(1,3)$.

Urethral injury and urethral fistula development are among the well-known complications of circumcision (4). The possible etiology of the urethral diverticulum in our case was thought to be an injury at the ventral aspect of the urethra due to plastic circumcision clamping. It was thought that the continuous urinary leakage from the urethral injury point and accumulation of urine in this area caused urethral epithelization and formation of the diverticulum. Plastic circumcision clamps have been increasingly applied in recent years due to their low costs and successful results (4). As with all circumcision techniques, it should be kept in mind that these plastic circumcision clamps may also cause a urethral injury and serious complications such as urethral diverticulum.

\section{Ethics}

Informed Consent: Informed consent was obtained from the parent.

Peer-review: Externally peer-reviewed.

\section{Authorship Contributions}

Concept: Ö.B., Design: Ö.B., A.K., Data Collection or Processing: Ö.B., I.K., A.K., Analysis or Interpretation: Ö.B., I.K., A.K., Literature Search: Ö.B., I.K., A.K., Writing: Ö.B., A.K.

Conflict of Interest: No conflict of interest was declared by the authors.

Financial Disclosure: The authors declared that this study received no financial support.

\section{References}

1. Rimon U, Hertz $M$, Jonas P. Diverticula of the male urethra: a review of 61 cases. Urol Radiol 1992;14:49-55.

2. Smith SEW. Unexpected anterior urethral diverticula. Clin Radiol 1986;37:55-58.

3. Kkhattala K, Rami M, Elmadi A, Chater L, Mahmoudi A, Bouabadallah Y. Giant urethral diverticulum's caused by traumatic vesicle catheterization in children: A case report. Pan Afr Med J 2011;10:15.

4. Tuncer AA, Erten EEA. Examination of short and long term complications of thermocautery, plastic clamping, and surgical circumcision techniques. Pak J Med Sci 2017;33:1418-1423. 